\title{
Runoff and Sediment Load from the Right Bank Valleys of Mosul Dam Reservoir
}

\author{
Mohammad Ezz-Aldeen Mohammad ${ }^{1}$, Nadhir Al-Ansari ${ }^{2}$ and Sven Knutsson ${ }^{2}$ \\ 1. College of Engineering, Mosul University, Mosul 41002, Iraq \\ 2. Department of Civil, Environmental and Natural Resources Engineering, Lulea University of Technology, Lulea 97187, Sweden
}

\begin{abstract}
Mosul Dam is a Multipurpose Project on the River Tigris in Iraq with 11.11 billion $\mathrm{m}^{3}$ storage capacity. It is used to store the water for irrigation, hydropower generation, and flood control. As in other dams in the world, this dam also have sedimentation problem. Sediment accumulation in its reservoir can effect the dam operation (pumping station, hydropower plants, and bottom outlets) and it will definitely shorten the life span of the dam. In this study, the SWAT (soil and water assessment tool) under GIS (Geographical Information System) was applied to simulate the yearly surface runoff and sediment load for the main three valleys on the right bank of Mosul Dam Reservoir. The simulation considered for the twenty one years begin from the dam operation in 1988 to 2008 . The resultant values of the average annual sediment load are $35.6 \times 10^{3}, 4.9 \times 10^{3}$, and $2.2 \times 10^{3}$ ton, while the average values of sediment concentration are $1.73,1.65$, and $2.73 \mathrm{~kg} / \mathrm{m}^{3}$ for the considered valleys one, two and three respectively. This implies that significant sediment load enters the reservoir from these valleys. To minimize the sediment load entering the reservoir, a check dam is to be constructed in suitable sites especially for valley one. The check dam can store the runoff water and trap the sediment load, and then the flow can be released to the reservoir.
\end{abstract}

Key words: Mosul dam, runoff, sediment load, SWAT model, GIS.

\section{Introduction}

Deposition of sediment in reservoirs can cause serious problems. They reduce the storage capacity of the reservoir and they can cause serious problems concerning the operation and stability of the dam [1]

One of the important factors in reservoirs design and operation is the sedimentation problem. Sediment delivered to the reservoir comes from two main sources. The first source is the main river entering the reservoir and the second source is the side valleys on both sides of the reservoir.

Due to the importance of the problem several empirical methods were developed and later modeling techniques was adopted [2].

Several types of models are used to predict sediment load among these Refs. [3-11]. In 2008, Ref. [12] developed the SWAT ArcView GIS Patch II for steep

Corresponding author: Nadhir Al-Ansari, professor, research field: water resources and environmental engineering. E-mail: nadhir.alansari@ltu.se. slope watersheds. Ref. [13] applied these models and got good results on Apucaraninha River watershed in southern of Brazil. Ref. [14] reviewed and introduced a number of selected papers which present and applied the SWAT (soil and water assessment tool).

Mosul dam is one of the biggest dams in Iraq, the dam is a multipurpose project, for flood control, irrigation, power generation, and water supply. In the last few years, sediment accumulation near the pump station that supply the irrigation water for Al-Jazera irrigation project appeared, which is one of the important projects in North of Iraq. This problem is becoming more severe with time and it is affecting the pumping rate and irrigation schedule of the project. The source sediment is from the main river and others runoff flow of valleys around the reservoir.

The objective of this study is to estimate the runoff volume and sediment loads entering Mosul Dam Reservoir from the main valleys on the right bank side. The accumulated yearly runoff and sediment loads 
were estimated for the period from 1988-2008. This period represent the first 21 years of the life operation of the dam.

\section{Study Area}

The studied area is located north of Iraq on the right bank of Mosul Dam reservoir (Fig. 1). The dam is about $60 \mathrm{~km}$ north of Mosul City. There are three main valleys that pour the runoff and the sediment load in the reservoir directly. High percent of studied area is a planted with seasonal crops (wheat and barley), vegetables and pastures, while the soil classification is mostly of silty loam, silty clay loam, and clay $[15,16]$. Table 1 shows the topographic properties of the three studied valleys 1, 2, and 3 (Fig. 1).

For valley one shown in Fig. 2a, the maximum elevation is 770.2 meters above sea level, and the minimum elevation near the outlets is 313.5 meters. About $96 \%$ of the valley area is covered with a winter wheat crop, while the remaining $4 \%$ is a pasture land. The soil classification distribution is $63 \%$ of silty loam,
$27 \%$ is silty clay loam, and the remaining $10 \%$ is clay soil. For valley two shown in Fig. 2b, the maximum elevation is 449.3 meters, and the minimum elevation is 306.5 meters. The crop cover area is $67.3 \%$ with winter wheat and vegetables, and $32.7 \%$ is pasture lands. The soil classification is $64 \%$ is silty loam, $25.6 \%$ clay, and the remaining $10.4 \%$ is silty clay loam. For valley three shown in Fig. 2c, the maximum elevation is 543.5 meters, and the minimum elevation near the outlet is 313.9 meters, about $46.2 \%$ of the total area in valley three is covered with wheat crop, $45.2 \%$ agricultural lands, and remaining $8.6 \%$ is pasture lands. The soil classification is $68.4 \%$ silty loam, $20.9 \%$ silty clay loam, and $10.7 \%$ is clay soil.

\section{Application of the Model}

SWAT (soil and water assessment tool) is a physically based model was developed to simulate and predict the runoff, sediment load, and agricultural chemical yields for large and complex watersheds having different soil type [17].

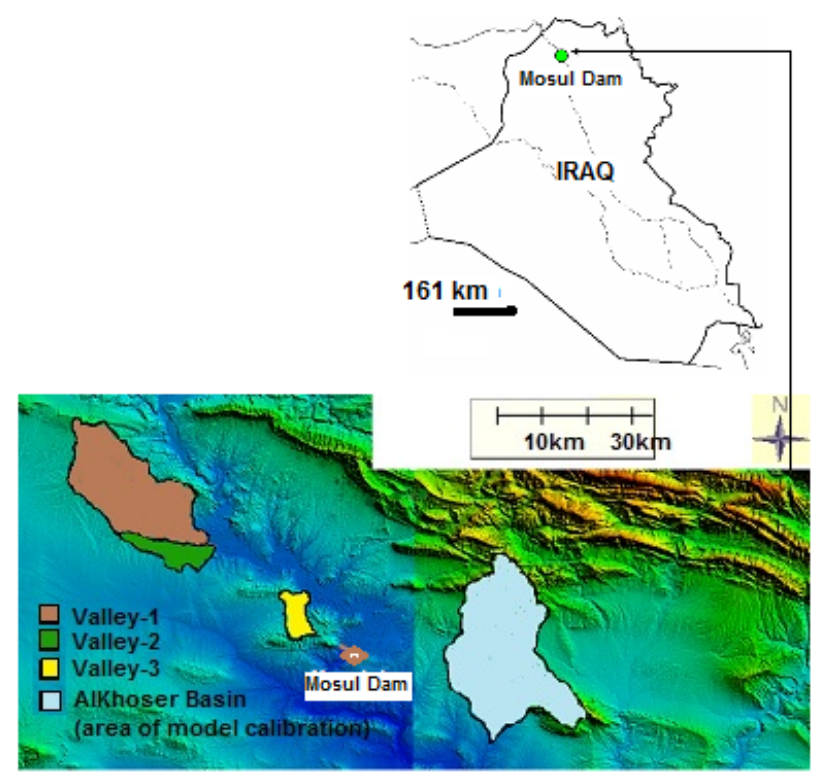

Fig. 1 Location of Mosul dam with the main valleys in the right bank.

Table 1 The topographic properties of the main valleys in the right bank of Mosul dam.

\begin{tabular}{llllll}
\hline Valley No. & Area $\left(\mathrm{km}^{2}\right)$ & Slope $\%$ & Length $(\mathrm{km})$ & Shape factor & Average level (meters) \\
\hline 1 & 450.76 & 3.59 & 38.80 & 3.5 & 446.62 \\
2 & 78.52 & 2.17 & 21.82 & 6.09 & 388.38 \\
3 & 50.06 & 5.25 & 10.86 & 2.36 & 404.89 \\
\hline
\end{tabular}



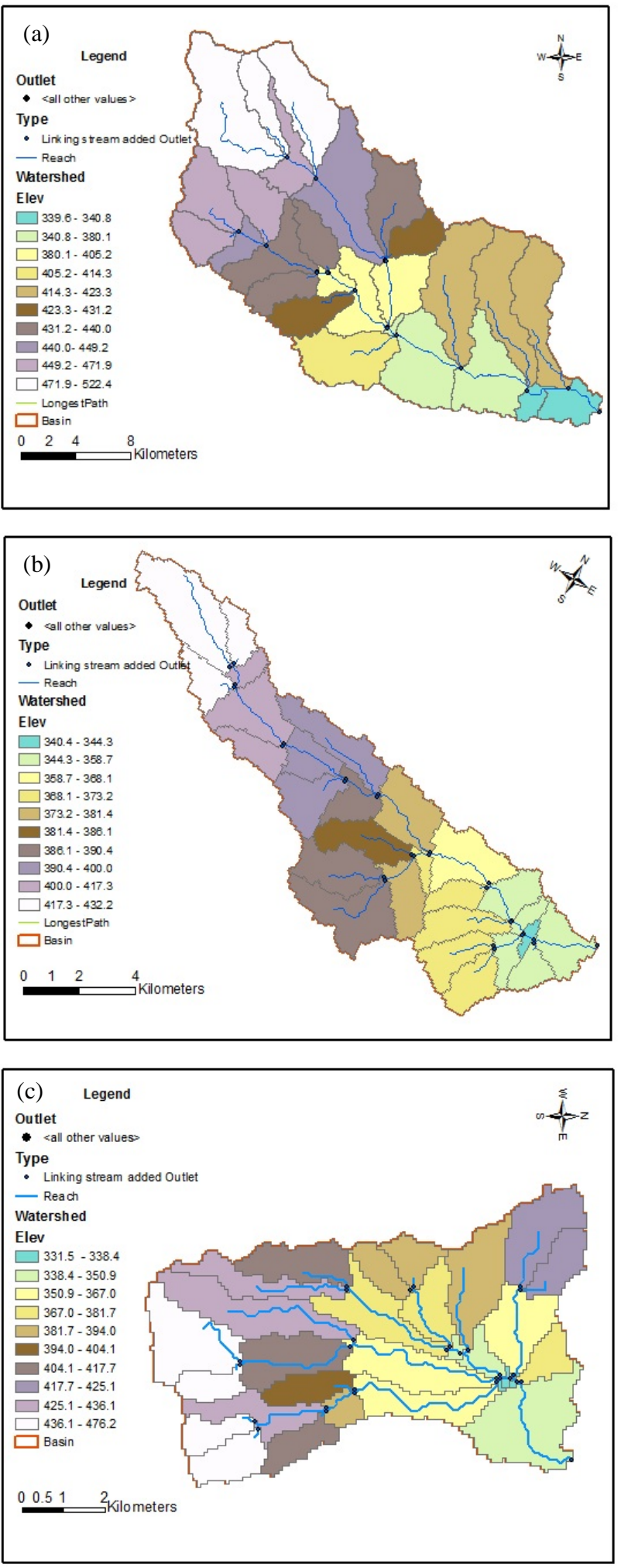

Fig. 2 Watershed boundary, sub-basins elevation, and flow net: (a) for valley-1; (b) for valley-2; (c) for valley-3.

In SWAT model, the surface runoff is estimated by two methods [18]: curve number procedure, and
Green-Ampt infiltration method. In curve number method the values of the curve number $\left(\mathrm{CN}_{2}\right)$ which is the tabulated curve number considered for average conditions. These values corrected for dry condition $\left(C N_{1}\right)$ and for moisture conditions $\left(C_{3}\right)$. The Green-Ampt infiltration method [19], on which the effective hydraulic conductivity is estimated based on saturated hydraulic conductivity and curve number as given by [20].

In SWAT model the estimation of erosion and sediment load yields based on MUSLE (modified universal soil loss equation) (Williams 1995 as quoted by Ref. [21]).

In order to verify and evaluate the model's results in the studied area, similar watershed was used. This watershed referred to as al-Khoser Seasonal River near the study area (Fig. 1).

The selected watershed is similar to the studied area in geology, surface soil and climate [22].

The studied area covers about $695 \mathrm{~km}^{2}$. The main part of the area is a silty clay loam, silty clay, silty loam, which covers $72 \%, 6 \%$, and $4 \%$ respectively. The remaining $18.0 \%$ is composed of dolomite, limestone, marl and marly limestone, which is very tough and highly jointed and fractured, and cannot be used for agricultural practices [23, 24]. Three single storms were measured in this area [24], including the rainfall depth, runoff and sediment hydrographs. These storms were simulated in SWAT Model to evaluate and calibrate the model to be verification for the studied area. The observed and simulated runoff depth and sediment load for the three considered storm are shown in Table 2.

The results showed a good agreement between the observed and simulated values for both runoff volume and sediment load, for the runoff volume, the determination coefficient between observed and simulated values is 0.94 and the Nash-Sutcliffe, model efficiency value (E) is 0.81 . Also for the sediment load, the determination coefficient and Nash-Sutcliffe model Efficiency values were 0.92 and 0.77 for the 
Table 2 Observed and simulated runoff volume and sediment load for the considered storm of model verification.

\begin{tabular}{|c|c|c|c|c|c|c|c|}
\hline \multirow{2}{*}{ Storm No. } & \multirow{2}{*}{ Date } & \multirow{2}{*}{ Rain (mm) } & \multicolumn{2}{|c|}{ Observed Runoff Simulated Runoff Observed } & \multicolumn{3}{|c|}{ Average Simulated Average Sediment } \\
\hline & & & Volume (MCM) & Volume (MCM) & Sediment Load $\left(* 10^{3}\right.$ ton $)$ & Load $\left(* 10^{3}\right.$ ton $)$ & \\
\hline I & 19/2/03 & 19 & 0.912 & 0.806 & 1.68 & 1.325 & \\
\hline II & $15 / 1 / 04$ & 9 & 0.130 & 0.139 & 0.078 & 0.158 & \\
\hline III & $22 / 1 / 04$ & 17 & 1.390 & 1.772 & 2.933 & 3.830 & \\
\hline
\end{tabular}

considered storms. This implies that the correlation is good and there is no significant difference between observed and simulated values.

\section{Results and Discussion}

The daily rainfall data, maximum and minimum temperature, sunshine, humidity, and wind speed of Mosul Dam and Mosul stations for the period 1988 to 2008 were considered in this study. The data were used to estimate the annual runoff volume and sediment load that delivered from the main valleys of right bank on Mosul Dam Reservoir. The SWAT (soil and water assessment tool) was considered for yearly simulation for both runoff and sediment of the three considered valleys.

The results of total annual runoff volume indicate that the average values are $20.6 \times 10^{6}, 3.1 \times 10^{6}$, and $0.8 \times 10^{6} \mathrm{~m}^{3}$ for valleys one, two, and three respectively (Fig. 3a-3c).

Table 2 Observed and simulated runoff volume and sediment load for the considered storm of model verification.

The contribution of these valleys for the reservoir inflow rate is limited. The maximum annual runoff volume for the considered valleys was in 1993 $\left(62.0 \times 10^{6}, 9.7 \times 10^{6}\right.$ and $2.8 \times 10^{6} \mathrm{~m}^{3}$ for the three valleys respectively) which are due the maximum annual rainfall depth in that year $(656 \mathrm{~mm})$. The minimum runoff volume were $0.28 \times 10^{6}, 0.021 \times 10^{6}$, and $0.02 \times 10^{6} \mathrm{~m}^{3}$ for the three valleys respectively for the year 2008 which had a minimum average annual rainfall depth of $78 \mathrm{~mm}$.

The results of sediment load indicate that the average annual load carried by the runoff flow is $35.6 \times 10^{3}, 4.9 \times 10^{3}$, and $2.2 \times 10^{3}$ ton for the three valleys respectively (Fig. 4a-4c). From these figures, we can see that the sediment concentration is highly fluctuating with time. This is due to the effect of rainfall intensity variation and other factors
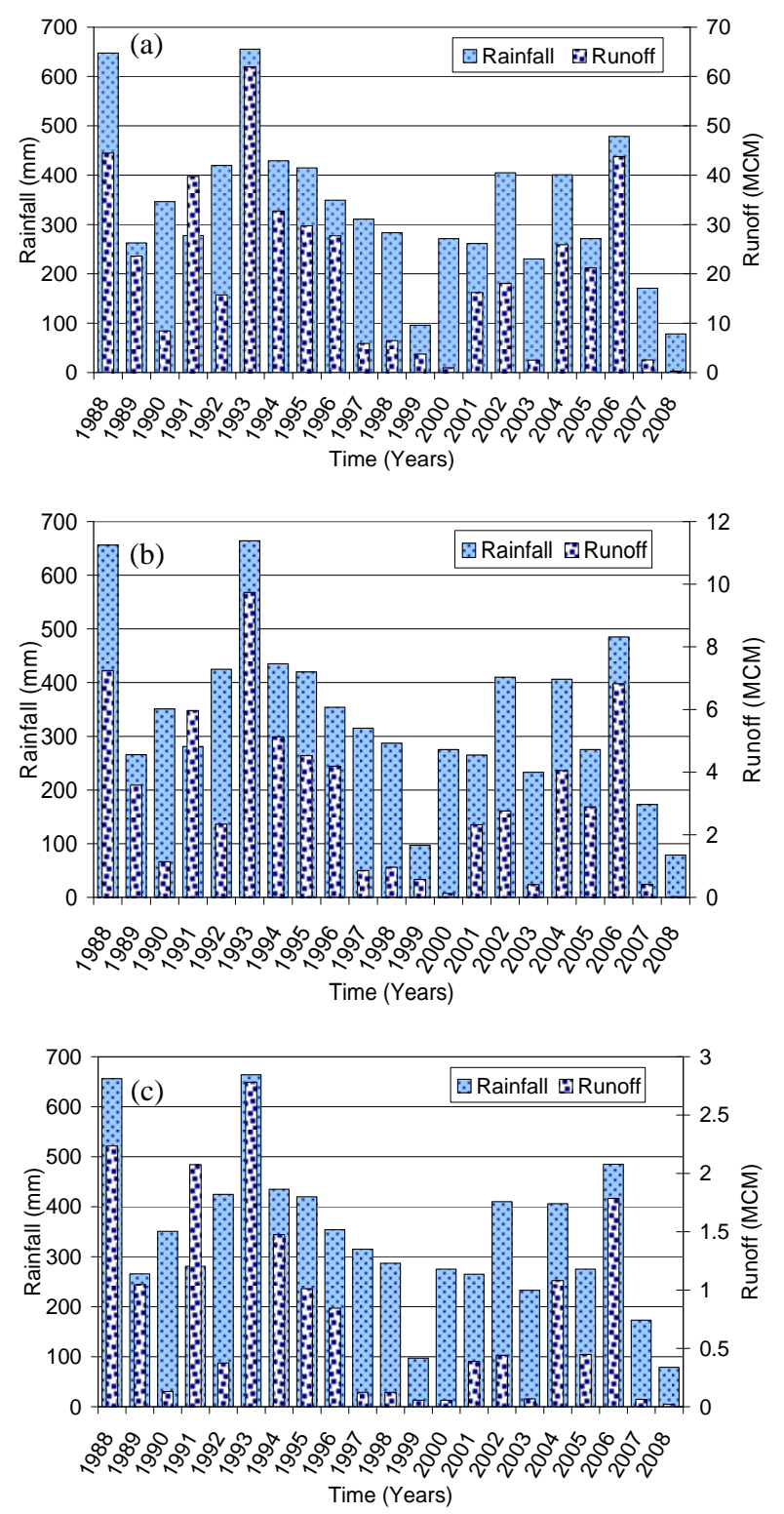

Fig. 3 Yearly rainfall depth and runoff volume: (a) for valley-1; (b) for valley-2; (c) for valley-3 for the considered period. 
effecting sediment load concentration. The maximum sediment concentrations are $3.2,2.7$, and $4.5 \mathrm{~kg} / \mathrm{m}^{3}$ for the selected valleys respectively for the year 1988 . The maximum rainfall intensity in that year was $63 \mathrm{~mm} /$ day. The number of rainy days in that year was little while the intensity was high (35, 30 and 20 mm/day) and this was reflected on sediment concentration. During the year (1993) also relatively high sediment concentration can be recognized. In this year the rainfall depth and runoff volume was the maximum, while the sediment load was not at its maximum value. This is due to the
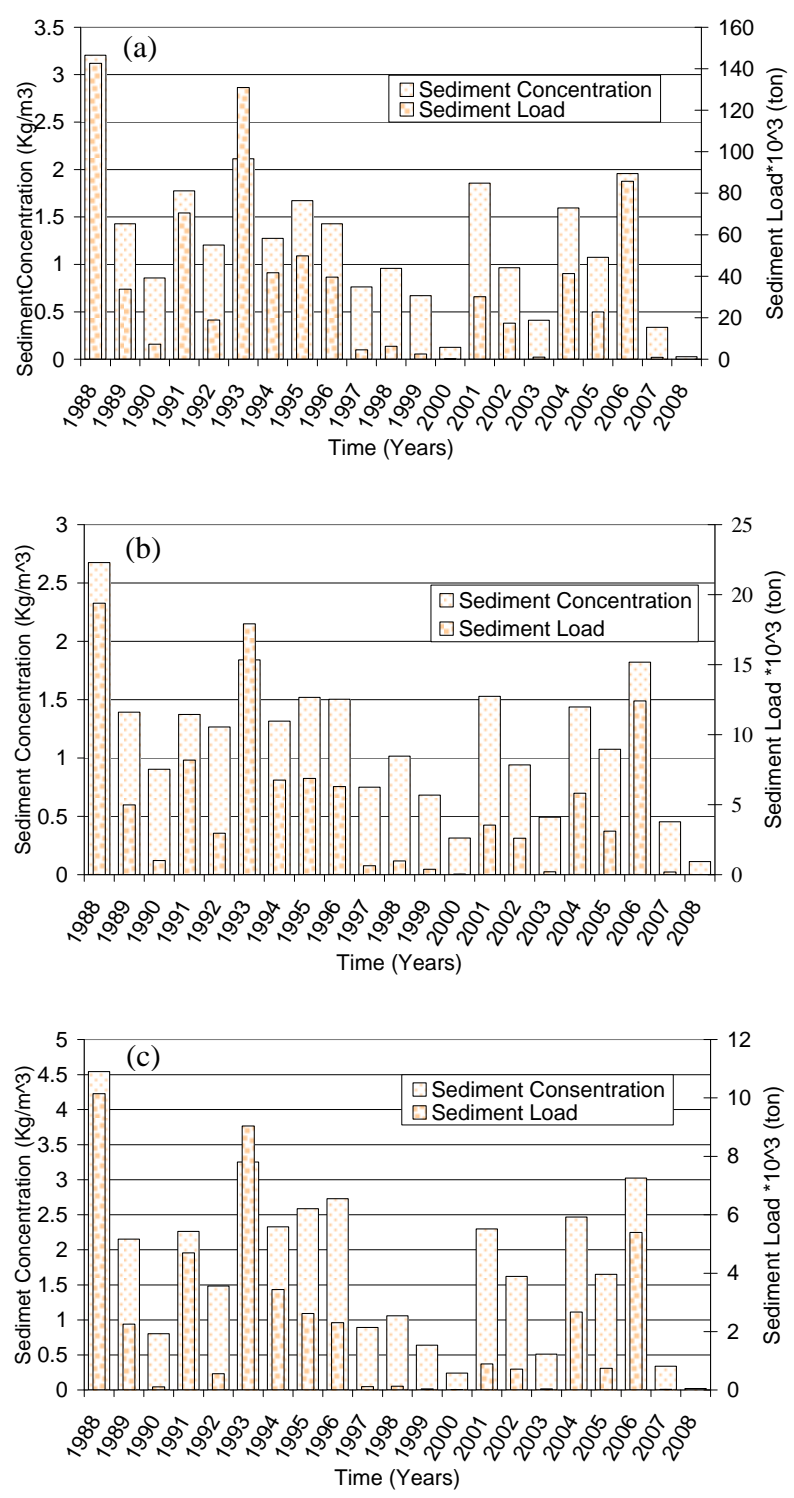

Fig. 4 Yearly sediment load and sediment concentration: (a) for valley-1; (b) for valley-2; (c) for valley-3 for the considered period. fact that the rainy days having effective rainfall depth are distributed along the rainy season with maximum intensity of $55 \mathrm{~mm}$.

The maximum annual sediment loads took place in $1988\left(142.56 \times 10^{3}, 19.38 \times 10^{3}\right.$, and $10.15 \times 10^{3}$ ton $)$ for the selected valleys respectively (Figs. 4a-4c). This year had the maximum annual rainfall depth of $656 \mathrm{~mm}$ and maximum runoff volume for all the valleys.

\section{Conclusions}

The SWAT-2009 (soil and water assessment tool) working under GIS (Geographical Information System) was applied to estimate the yearly runoff and sediment load carrying from the main valleys at the right bank of Mosul Dam Reservoir. The simulation of the runoff and sediment load extended for twenty one years starting 1988. The objective is to estimate the total load that was carried with the runoff flow and delivered directly in to the reservoir. The results indicates that total annual sediment load entering the reservoir from the right bank valleys have a significant amount. This has negative effect on reservoir storage capacity and different hydraulic structures. The total sediment load of the considered period reaches to $747.5 \times 10^{3}$ ton for valley one, $104.3 \times 10^{3}$ ton for valley two, and $45.9 \times 10^{3}$ ton for valley three. This makes the total volume of sediment entered within the reservoir $716.2 \times 10^{3} \mathrm{~m}^{3}$. From these values, the average annual rate of erosion in the studied valleys is $78.9,62.4$, and $43.9 \mathrm{ton} / \mathrm{km}^{2}$ respectively. These values of sediment load must be considered especially for valley one, a check dam in a suitable site may be constructed to store the temporary runoff water for a short period to settle the sediment load and then release the runoff to the main reservoir with minimum load.

\section{References}

[1] C. T. Yang, Sediment Transport: Theory and Practice, McGraw Hill, NY, 1996, p. 395.

[2] U.S. Department of Interior, Bureau of Reclamation, Erosion and Sedimentation Manual, US Department of Interior, Bureau of Reclamation, Technical Service Center, Sedimentation and River Hydraulic Group, 
Denver, Colorado, 2006, p. 508.

[3] R. Srinivasan, T. Ramanarayanan, G. Arnold and S. Bednarz, Large area hydrologic modeling and assessment Part-II model application, J. of the American water Resources Association 34 (1) (1998) 91-101.

[4] C. Fernandez, J. Wu, D. McCool and C. Stockle, Estimation water erosion and sediment yield with GIS, RUSLE, and SEDD, J. of Soil and Water Conservation 58 (3) (2003) 128-136.

[5] H. Kim, Soil erosion modeling using RUSLE and GIS on the IMHA Watershed, South Korea, Master Thesis, Colorado State University, Colorado, USA, 2006.

[6] A. Yüksel, A. Akay, R. Gundogan, M. Reis and M. Cetiner, Application of GeoWEPP for determining sediment yield and runoff in the Orcan Creek Watershed in Kahramanmaras, Turkey 8 (2008) 1222-1236.

[7] G. Baigorria and C. Romero, Assessment of erosion hotspots in a watershed: Integrating the WEPP model and GIS in a case study in the Peruvian Andes, Environmental Modelling and Software 22 (2007) 1175-1183.

[8] T. Engda, Modeling rainfall, runoff and soil loss relationships in the northeastern highlands of Ethiopia, audit tide watershed, M.Sc. Thesis, Cornell University, USA, 2009, p. 84.

[9] I. Gitas, K. Douros, C. Minakou, G. Silleos and C. Karydas, Multi-temporal soil erosion risk assessment in N. chalkidiki using a modified usle raster model, in: EARSeL e-Proceedings 8 (2009) 40-52.

[10] V. Nangia, P. Wymar and J. Klang, Evaluation of a GIS-based watershed modeling approach for sediment transport, International Journal of Agricultural and Biological Engineering 3 (3) (2010) 1-11.

[11] M. Jain, S. Mishra and R. Shah, Estimation of sediment yield and areas vulnerable to soil erosion and deposition in a Himalayan watershed using GIS, Current Science 98 (2) (2010) 213-221.

[12] J. G. Kim, Y. Park, D. Yoo, N. Kim, B. Engel and S. Kim et al., Development of a SWAT ArcView GIS patch for accurate analysis of soil erosion and sediment yield at steep sloping watershed, in: American Society of Agricultural and Biological Engineers Annual International Meeting 9 (2008) 5282-5287.
[13] I. D. Santos, M. Andriolo, R. Gibertoni and M. Kobiyama, Use of the SWAT model to evaluate the impact of different land use scenarios on discharge and sediment transport in the Apucaraninha River watershed, southern Brazil, International association of hydrological science 337 (2010) 322-328.

[14] K. R. Doughlas-Mankin, R. Srinivasan and J. G. Arnold, Soil and water Assessment tool (SWAT) model: Current development and application, Transaction of ASABE 53 (5) (2010) 1423-1431.

[15] A. Mohammad, Using remote sensing data to evaluate land use for some soil properties south west Mosul Dam Reservoir, Master Thesis, University of Mosul, Mosul, Iraq, 2006.

[16] H. S. Al-Daghastani, Land Use and Land Cover Map of Nineah Governorate Using Remote Sensing Data, Remote Sensing Center, Mosul University, Iraq, 2008.

[17] B. Ashagre, SWAT to identify watershed management option: (Anjeni Watershed, Blue Nile Basin, Ethiopia), Master Thesis, Cornell University, New York, USA. 2009.

[18] M. Winchell, R. Srinivasan, M. Di Luzio and J. Arnold, ARCSWAT interface for SWAT 2005, User guide. Blackland Research Center, Texas Agricultural Experiment Station, and Grassland, Soil and Water Research Laboratory, USDA Agricultural Research Services, Texas, USA, 2007, p. 341.

[19] V. T. Chow, D. R. Maidment and L. W. Mays, Applied Hydrology, McGraw Hill, NY, 1988, p. 572.

[20] M. Nearing, B. Liu, L. Risse and X. Zhang, Curve number and Green-Ampt effective hydraulic conductivity, WRB, American Water Resources Association 32 (1) (1996) 125-136.

[21] V. Chaplot, Impact of DEM mesh size and soil map scale on SWAT runoff, sediment, and NO3-N, loads predictions, Journal of Hydrology 312 (2005) 207-222.

[22] S. Z. Jassim and J. C. Goff, Geology of Iraq, Dolin, Prague and Moravian Museum, Brno, 2006, p. 341.

[23] S. Q. Al-Naqib, Geology of Atrush area, Master Thesis, University of Mosul, Mosul, Iraq, 1980.

[24] E. M. Mohammad, A Conceptual Model for Flow and Sediment Routing for a Watershed Northern Iraq, Doctoral Thesis, University of Mosul, Mosul, Iraq, 2005. 